\title{
Perioperative Management of a Giant Ovarian Tumour in an Adolescence with Severe Scoliosis and Unilateral Diaphragmatic Dysfunction: A Case Report
}

\author{
Gezy Weita Giwangkancana, ${ }^{1}$ Andi Kurniadi, ${ }^{2}$ Yunita Susanto Putri, ${ }^{3}$ Euis Maryani $^{4}$ \\ ${ }^{1}$ Department of Anaesthesiology and Intensive Care, Faculty of Medicine Universitas Padjadjaran/ \\ Dr. Hasan Sadikin General Hospital Bandung Indonesia, ${ }^{2}$ Department of Obstetrics and Gynaecology, \\ Faculty of Medicine Universitas Padjadjaran/Dr. Hasan Sadikin General Hospital Bandung, \\ Indonesia, ${ }^{3}$ Department of Anaesthesiology and Intensive Care, Santosa Hospital Bandung Kopo \\ Indonesia, ${ }^{4}$ Department of Surgery, Cardiothoracic and Vascular Division, Faculty of Medicine \\ Universitas Padjadjaran/Dr. Hasan Sadikin General Hospital Bandung Indonesia
}

\begin{abstract}
Though giant ovarian tumor are rare but due to the limitations in oncology surgery during the COVID-19 pandemic, many oncology patients are presented with a more severe stage and giant ovarian tumors may be more commonly seen during this period. The aim of this case report study was to describe the perioperative management of an adolescent patient with a giant ovarian tumor, severe scoliosis, and unilateral diaphragm dysfunction. An 18-years-old girl weighing $28 \mathrm{kgBW}$ came with a giant abdominal mass that extended to her thoracic and back areas. The patient had a history of severe scoliosis since childhood. She had signs of respiratory distress and was not comfortable lying down. Preoperatively, the surgeon used ultrasonography to guide cyst puncture using a thoracic tube and 6,500 cc of mucinous fluid was drained. Inhalational induction with preservation of spontaneous breathing was performed. Two massive masses filled the entire abdominal area, adhering to the peritoneum while pushing and tenting the diaphragm cranially and laterally to the right and bilateral salpingo-oophorectomy was conducted. Serial radiological examinations showed unilateral diaphragmatic dysfunction and a progressing ventilator associated pneumonia. Improving postoperative outcome of patients with giant intraabdominal masses must include preoperative assessment of potential peri-operative respiratory complications, preparation of intraoperative hemodynamic, and ventilatory disturbances with gentle weaning and multidisciplinary approach during the post-operative care to assess readiness of ventilator weaning.
\end{abstract}

Key words: Adolescence, diaphragm dysfunction, malignancy, ovarian tumour, surgery

\section{Manajemen Perioperatif Pasien dengan Tumor Ovarium Permagna pada Remaja dengan Skoliosis Berat dan Gangguan Diafragma Unilateral}

\begin{abstract}
Abstrak
Tumor ovarium berukuran masif pada anak jarang ditemukan di masa moderen karena perbaikan sistem pelayanan kesehatan namun di masa COVID-19, kasus dapat ditemukan karena hambatan pelayanan pembedahan onkologi. Laporan kasus ini bertujuan melaporkan manajemen perioperatif pada pasien remaja dengan tumor ovarium massif, skoliosis berat dan disfungsi diafragma. Remaja berusia 18 tahun dengan berat 35 kilogran datang dengan massa abdomen sangat besar disertai riwayat skoliosis. Pasien memiliki tanda ancaman gagal napas dan tidak nyaman pada posisi berbaring dan hanya dapat beristirahat dalam posisi duduk. Sebelum induksi, dokter bedah melakukan punksi massa dan didapatkan 6.500 cc cairan musin. Pasien diinduksi dengan napas spontan menggunakan gas anestesi. Bilateral salfingoofarektomi dilakukan dan pascaoperasi pasien dirawat di ruang intensif. Selama masa pemulihan pasien sulit disapih dari ventilator dan hasil pemeriksaan radiologis berulang menunjukkan tanda disfungsi diafragma dan pneumonia. Simpulan, meningkatkan hasil keluaran pada pasien dengan massa intraabdomen massif harus meliputi pemeriksaan preoperatif yang cermat mengenai komplikasi pernafasan perioperative, persiapan permasalahan hemodinamik intraoperative dan strategi penyapihan dari ventilator yang efektif dengan melibatkan pendekatan multidisiplin.
\end{abstract}

Kata kunci: Disfungsi diafragma, bedah, onkologi, remaja, skoliosis, tumor ovarium

Correspondence: Gezy Weita Giwangkancana, dr., SpAn, Department of Anaesthesiology and Intensive Care, Faculty of Medicine Universitas Padjadjaran/ Dr. Hasan Sadikin General Hospital Bandung Indonesia, Jl. Pasteur No. 38 Bandung 40161, Phone 022 2038285, Email gezy.weita@unpad.ac.id 


\section{Introduction}

Ovarian tumors are uncommon in children and constitute around $1 \%$ of childhood malignancies with two thirds of the case are germ cell tumors. The annual incidence of ovarian tumors is 2.2 per 100,000 females and approximately half of the ovarian masses in pediatrics and adolescence are neoplastic in nature. Common symptoms on admission were acute abdominal main (48.9\%) and abdominal mass $(40.4 \%)$ with the mean age of presentation at $10-14$ years old. ${ }^{1,2}$

During the COVID-19 pandemic, oncology surgery and surgery in general saw severe restrictions on its capacity. Many patients are unable to receive timely care and surgery because hospitals need to redirect its resources and capacity for managing COVID-19 cases. A side effect of this policy is that many oncology patients will come with a more severe stage of their illness. ${ }^{3,4}$ Due to this scenario, giant abdominal masses such as giant ovarian tumors may commonly be seen in daily surgery.

A careful preoperative planning and management for giant ovarian tumors must include mitigation of several possible perioperative complications. A large mass in the abdominal area may cause supine hypotensive syndrome and ventilatory failure driven by the chronic compression of the tumor. A rapid decrease of pressures after tumor removal can induce sudden hemodynamic collapse and re-expansion of pulmonary edema. $^{5-7}$ Perioperative complication is more likely if the patient has other comorbidities especially those impacting respiration capacity such as scoliosis. Severe scoliosis tends to cause restrictive ventilation defect along with ventilation perfusion mismatch and hypoxemia..$^{8-10}$

Possible intraoperative hemorrhage, postoperative respiratory problems, and acute pain due to a large incision are some complications needed to be addressed by the anesthetic, surgical, intensive, and rehabilitation team. The aim of this case report study was to describe the perioperative management of an adolescent patient with a giant ovarian tumor, severe scoliosis, and unilateral diaphragm dysfunction.

\section{Case Report}

An 18-years-old girl weighing $28 \mathrm{kgBW}$ came with a giant abdominal mass that had developed since 3 years ago. She was examined in a national referral hospital in early 2019 and was scheduled for surgery; however, due to the COVID-19 pandemic, the referral hospital had delayed her surgery due to low capacity. Her family then decided to admit her to a district hospital in February 2020 because she started to have difficulties in breathing and could not lie down in a supine position. She had also reported episodes of severe bloating and, within the last month before she was presented to the hospital, she was unable to do physical activities and was confined to her bed.

The patient had a history of severe scoliosis of her back since she was 8 years old and her lower extremities was also deformed with 6 toes on each foot and an 0-shaped legs. Preoperative assessment showed a distressed patient in the sitting position and was on free air with an oxygen saturation of $92 \%$ and respiration rate of 24-28 times per minute. (Figure 1) Supplemental oxygen via a non-rebreathing mask was given at 10 liters per minute and her saturation increased to $99 \%$ although signs of distress was still evidence. She had tachycardia at 128-130 beats per minute and blood pressure was $110 / 68 \mathrm{mmHg}$. Her radial pulse feels light to touch, both of her legs was edematous, and her overall nutritional status seems worrisome because she was weighing $35 \mathrm{kgBW}$ with the mass calculated. Auscultation of her lungs on the right side was normal but her left lungs breath sounds was limited to the apex. Her heart was heard also on the right hemithorax.

Due to limited resources in our hospital, only her routine blood work, chest x-ray, and COVID-19 antigen test results were available. Her hemoglobin was 13 grams/ $\mathrm{dL}$ and her chest $\mathrm{x}$-rays revealed a massive 


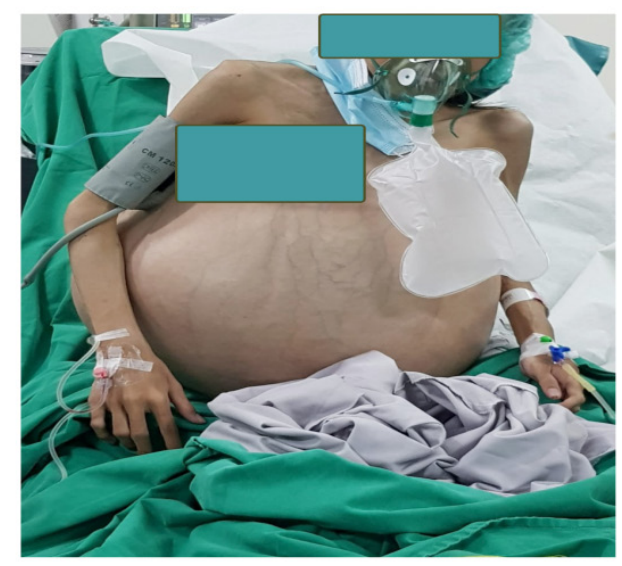

Figure 1 Clinical Presentation

abdominal mass that tented the diaphragms. (Figure 2) The mediastinum was severely shifted to the right side of her hemithorax. An ultrasonography revealed a massive cystic mass that was possibly originated from her ovaries. Considering the patient's physical condition, the patient was categorized as an American Society of Anesthesiologists (ASA) grade IV. Before surgery, 4 units of blood were
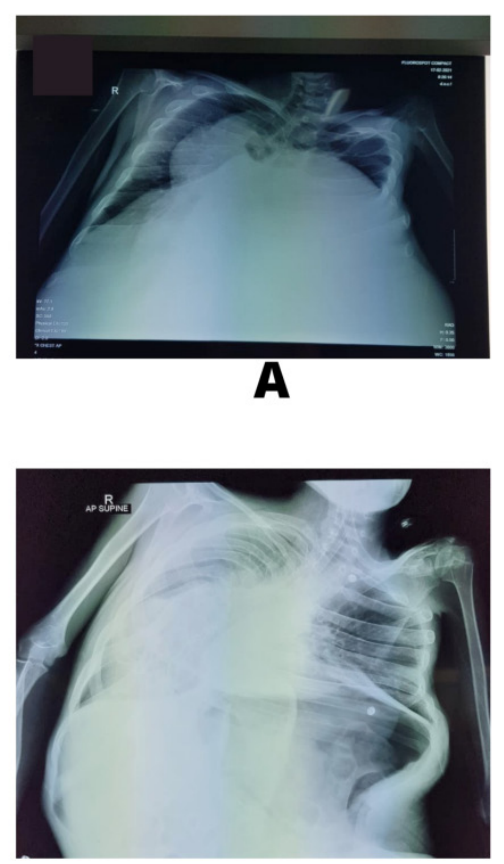

C

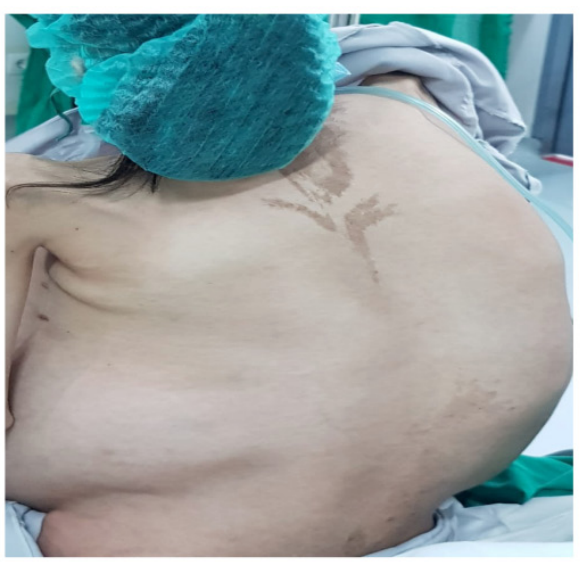

ordered and the availability of fresh frozen plasma and platelets was confirmed. The patient was fasted 8 hours prior to surgery.

Standard monitors were applied in the operating room. The baseline vital signs showed the followings: BP of $118 / 68 \mathrm{~mm} \mathrm{Hg}$, heart rate (HR) of 124 beats/min, respiratory rate of 26 times/min, body temperature of $36.3^{\circ} \mathrm{C}$, and saturation of $97 \%$ on 10 litters
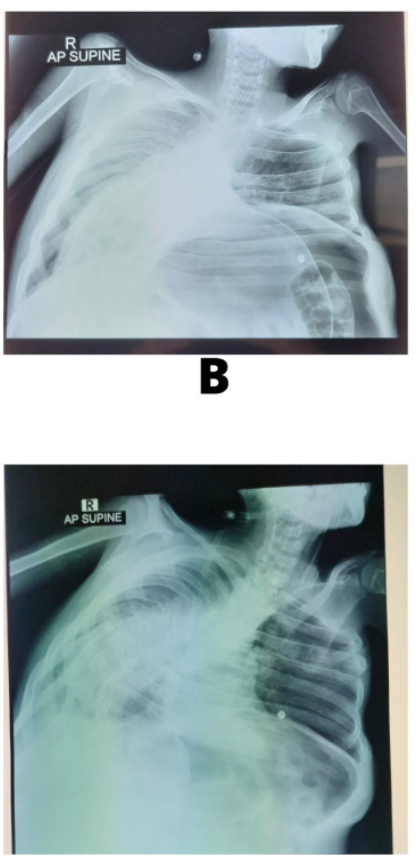

D

\section{Figure 2 Serial Chest X-Ray}

Figure A: preoperative; Figure B: post operative day 2; Figure C: post operative day 4; Figure D: post operative day 10 

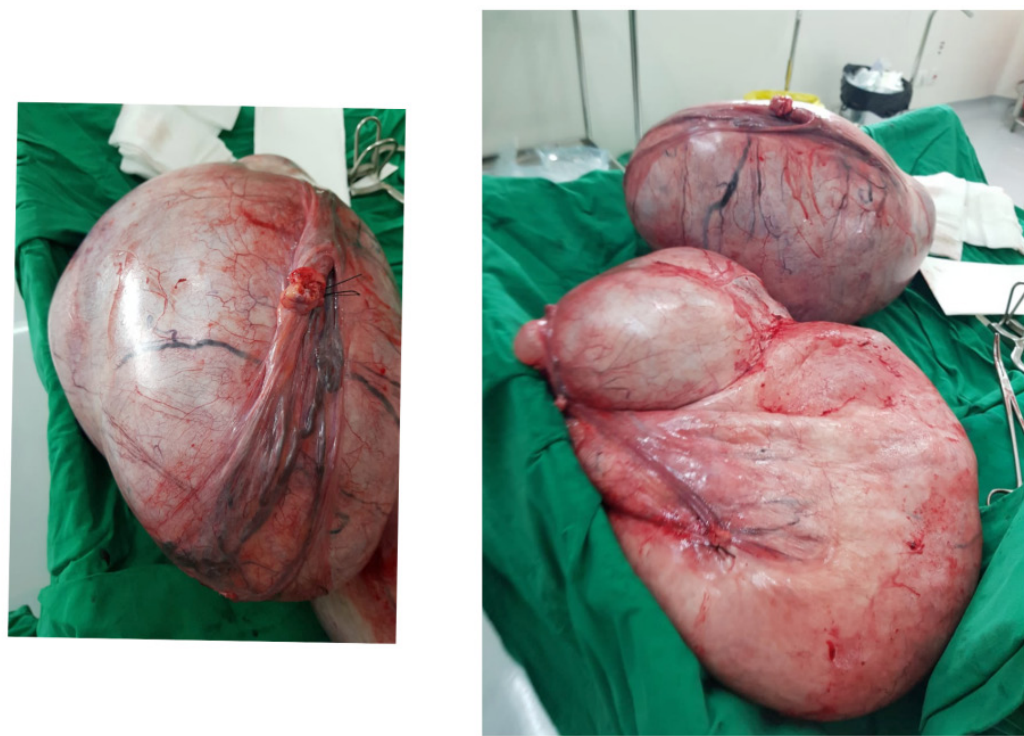

Figure 3 Mass Removed

of oxygen via a mask. The patient was in a fully sitting position and looked very uncomfortable. After a short discussion, the surgeon used local anesthetic to numb an area on her low right abdominal quadrant and used ultrasonography to guide puncture of her cyst using a thoracic catheter tube no 20. Approximately 6,500 cc of mucinous fluid was drained and her breathing somewhat improved with less signs of distress with a saturation of $100 \%$ on 10 litters of oxygen.

Lidocaine spray solution $10 \%$ was used on the patient's oropharyngeal area and the patient complained of its bitter taste while feeling slightly nauseous. Intravenous Ondansetron $4 \mathrm{mg}$ was given with $10 \mathrm{mg}$ of intravenous propofol to reduce her discomfort. Spontaneous inhalational anesthesia was chosenas themethodforinduction. Sevoflurane was titrated slowly from 1 to 8 vol\% in $100 \%$ oxygen and, after intubation condition was deemed possible, a laryngoscope was introduced to her airway and her larynx was noted. Another spray of lidocaine $10 \%$ was applied to her larynx and a 6.5 endotracheal tube was introduced. After the end tidal $\mathrm{CO}_{2}$ curve was noted, bilateral chest rise was not easily visible and, upon auscultation, only the apex part of her left chest had breathing sounds. No desaturation was noted during the intubation procedure and patient was spontaneously breathing. Her breathing was manually assisted in a $50 \%$ mixture of air, and the oxygen end tidal $\mathrm{CO}_{2}$ was at $25-28 \mathrm{mmHg}$ while the saturation was $100 \%$. Anesthesia was maintained with sevoflurane $1 \mathrm{vol} \%$ with a bolus of $15 \mathrm{mg}$ atracurium, $30 \mathrm{mg}$ ketamine, and 25 micrograms of fentanyl prior to incision to facilitate surgery. Ventilator was set to a tidal volume of $280 \mathrm{cc}$, post expiratory end pressure (PEEP) of $7 \mathrm{cmH}_{2} \mathrm{O}$ with a frequency of 20 times per minute and both her saturation and end tidal $\mathrm{CO}^{2}$ were maintained. Two 16 gauge intravenous like was started in preparation for massive bleeding.

In the abdomen, two round white greyish mass with silky surface was found arising from each ovary with approximate size of $60 \times 50 \times 40 \mathrm{~cm}$. (Figure 3) The two masses filled the entire abdominal area, adhering to the peritoneum while pushing and tenting the diaphragm cranially and laterally to the right. Although a total hysterectomy was planned with bilateral salpingo-oophorectomy (SOB) but the patient's parents did not agree with the hysterectomy and it was abandoned, rather a bilateral SOB was conducted. No bedside pathology examination was possible but further exploration of the abdominal cavity showed no mass infiltration to the caecum, 
colon, peritoneum, stomach, spleen, and kidneys. Analysis of tissue concluded a highgrade serous carcinoma on the first mass and mucinous cyst adenoma on the second mass.

Prior to mass removal, 2,000 cc of intravenous fluid was rapidly given. However, despite the preloading, her blood pressure dropped to $70 / 40 \mathrm{mmHg}$ during the mass removal and an infusion of norepinephrine 0.08-0.1 micrograms/kilogram/minute was started. Her hemodynamic was stable until the end of surgery with total bleeding of $1,200 \mathrm{cc}$ and one unit of packed red cell was given. She was transferred to the intensive care for further treatment. Upon assessment of clinical breathing condition and with stable hemodynamic parameters, she was extubated on the second day post op and was discharged to the gynecology ward on 3 liters per minute of oxygen via nasal cannula.

On the third day after surgery, the patient complained of sudden severe dyspnea with cough. Her breathing seems laborious and asymmetrical. Her breathing was at 36-40 times per minute with a saturation of $84 \%$ with 15 litters of oxygen via a non-rebreathing mask. Her blood pressure dropped to 80/40 mmHg and her heart rate was 169 times per minute. Upon auscultation, both of her lungs has wet bilateral rales. She was re-admitted to the intensive care and a non-invasive ventilation strategy using $100 \%$ oxygen and peep $6 \mathrm{~cm} \mathrm{H}_{2} \mathrm{O}$ was used. Her blood gas analysis showed a pH of $7.29, \mathrm{PCO}_{2}$ of 39.9 $\mathrm{mmHg}, \mathrm{PO}_{2}$ of $203 \mathrm{mmHg}$ in $100 \% \mathrm{O}_{2}$, and base excess of $-6.6 \mathrm{mmol} / \mathrm{L}$. Her breathing was clinically laborious and after evaluation of her decreasing ROX index, she was intubated 4 hours later and was put on mechanical ventilator.

During her second admission, she was fully conscious and obeyed command. During this time, she complained of constant "heaviness" on inhaling and was given on pressure support at $16-18 \mathrm{mmHg}$. She was re-intubated three times within the first week of her critical care time due to massive clot on her endotracheal tube and her radiographic x-rays showed worsening rounded pneumonia and an unusual high tenting of the left diaphragm (Figure 2) She was planned to be referred to the national referral hospital for computerized topographic scan (CT-scan) of her chest and consultation to a thoracic surgeon. Unfortunately, the patient passed away on the 14th day of critical care due to sepsis before any referral was made.

\section{Discussion}

Giant abdominal tumor is uncommon in this era due to greater access to health care and better health awareness. However, since COVID-19 pandemic started in early 2020, many oncology patients have to endure delay in their surgery due to decreasing hospital capacity for nonCOVID-19 patients. For aggressive cancers, analysis demonstrated that even a short delay (3 months) brings a significant impact on patient survival. However, even for cancers with a more favorable prognosis, a delay of 6 months will result in significant summed attributable deaths. Delay in surgery also results in tumors being more advanced, more costly to treat, requires advance resources (such as intensive care), and may inevitably present as emergencies.,3 Our case detailed that our patient had already came late upon initial presentation and her surgery was further delayed for almost 1 year, that possibly made her case more severe. The health system, hospitals, oncology surgeons, and anesthesiologist must prepare more resources and skills to manage more complicated and sicker oncology patients in the COVID-19 era.

There are several factors that increase perioperative respiratory complications on our patient. First, during the pre- and intraoperative period, the giant abdominal tumors interfered the respiratory function through severe elevation and splinting of the diaphragms with tenting of the rib cage. ${ }^{5-7}$ Reduced lung functional residual capacity and risk of desaturation prompted us to apply the preoxygenation strategy before intubation and a lung protective strategy was applied during surgery with a low tidal volume at 6 $\mathrm{cc} / \mathrm{kgBW}$ and PEEP of 6-7 $\mathrm{cm} \mathrm{H}_{2} \mathrm{O}$ to achieve satisfactory saturation and $\mathrm{EtCO}_{2}$. 
Secondly, prolonged exposure of the mass to the diaphragm may also cause damages to the respiratory muscles especially the diagram. As the diaphragm is a chief muscle of inspiration, unilateral paralysis can lead to dyspnea and can affect ventilatory functions. Studies on unilateral diaphragm paralysis showed that the most common etiology is phrenic nerves injury due to chronic pressure or splinting of the diaphragmatic muscles, both of which were found on this patient. The tentative diagnosis is usually made based on chest x-ray which, in our patient, presented an image of a unilateral high and stiff diaphragm, and the clinical exam showed a difficulty in ventilator weaning. Confirmation was conducted with phrenic nerve stimulation, diaphragm electromyography and/or fluoroscopy study, which are not available in our hospital. Surgery to repair the diagram function, such as plication of diaphragm surgery, could be carried out to improve the respiratory mechanics. ${ }^{8-10}$

Thirdly, the preoperative respiratory function was further complicated by the presence of severe scoliosis (Figure 2). Studies has shown that severe scoliosis and the progression of vertebral deformity leads to hypoxemia, hypercapnia, cor-pulmonale, and pulmonary hypertension. The most frequent pulmonary alteration in young patients, such us ours, is restrictive pulmonary disease. Spirometry, if available, will show decreased forced vital capacity (FVC), decreased forced expiratory volume in one second (FEV1), and normal FEV1/FVC ratio. Because of this respiratory impairment, patients have a high risk of postoperative respiratory complications with an FVC value of less than $40 \%$ of the theoretical value as the sign of severe respiratory compromise. ${ }^{11-12}$

Fourth, the development of re-expansion pulmonary oedema(RPE) on the 3rd day of surgery was noted on the patient's chest x-ray. When a chronically collapsed lung reexpands after an extended duration (generally after 72 hours), pulmonary edema sometimes occurs. On this patient, the left lower lobe of her lungs was compressed by the mass for a long period of time and a combination of mass removal and ventilatory techniques expanded the collapsed lungs. Note that our patient still had some areas of atelectasis on her last chest x-ray (Figure 2). RPE is uncommon but typically appears unexpectedly and rapidly. Due to the rapid blood inflow and sudden alveolar distension, there is an alteration of alveolus-capillary barrier. Paired with decrease surfactant, there was an increase in capillary permeability and increase in hydrostatic pressure, causing pulmonary edema on the third day. ${ }^{5-7}$ Lastly, additional acute post-operative pain, undernutrition, and muscle wasting due to inactivity may further add the severity to our patient's case. ${ }^{12}$

Although the ventilation strategy was able to provide her ventilatory support during her treatment but it also increased her risk of ventilator associated pneumonia (VAP) as she was intubated for 14 days. Some of the risks found on our patient for ventilator-associated pneumonia were post-operative acute respiratory failure, malnutrition, frequent intubation, and neuromuscular disorders. VAP is one of the major contributing factors to morbidity and mortality in ICU. Although we had applied the VAP bundle including elevation of the head by 30-45 degrees, daily sedation vacation, daily assessment of readiness to extubate, peptic ulcer disease prophylaxis, and deep venous thrombosis prophylaxis, our patient still developed VAP, which was possibly due to multiple perioperative respiratory complications risk mentioned above. ${ }^{13}$

Several imaging modalities such as ultrasound and CT scan ar used as the initial imaging modality in children with ovarian masses. A transabdominal ultrasound is usually the first imaging of choice and will help to distinguish between solid and cystic masses. CT scan will help to assess the nature and extent of tumor better and may also aid in predicting the chance of malignancy. Malignant tumors tend to be larger and more solid or heterogeneous than benign tumors. In contrast to other studies, our patient underwent exploratory laparotomy before CT imaging studies. 
To improve the post-operative outcome of patients with giant intraabdominal masses, we propose to apply the lessons learned from this case. First, during the preoperative period, an assessment should be made on the potential post-operative respiratory complications risks such as the size and chronicity of the mass, tenting of diaphragm, structural deformity of thoracic cage, and signs of malnutrition. Second, during the postoperative period, we suggest gentle weaning of these patients from the ventilator, starting on the third day, and close evaluation of possible re-expansion pulmonary edema and assessment of diaphragm function. Thirdly, in the Covid-19 pandemic era where referral is difficult and severe cases are unattained, palliative surgery such as gradual tumor fluid drainage using a makeshift tube such as a 10FR cystofix tube could be done in district hospitals before the actual surgery can be performed at the referral hospital since post-operative management have to include multi-disciplinary approach and advanced medical equipment which, perhaps, are not available in some hospitals.

\section{Conclusion}

To improve post-operative outcome of patients with giant intraabdominal masses, the preoperative period must include an assessment of potential post-operative respiratory complications. The intraoperative preparations of severe hemodynamic disturbance and ventilatory techniques must be chosen carefully. During the postoperative period, gentle weaning and multidisciplinary approach should be applied to assess the readiness for ventilator weaning. During the Covid-19 pandemic era, palliative surgery may be more commonly seen as preparation of definitive surgery.

\section{References}

1. Rajeswari B, Nair M, Ninan A, Parukuttyamma K. Ovarian tumors in children: 10-year experience from a tertiary care center in South India. Indian
J Cancer. 2016 Apr-Jun;53(2):292-5. doi: 10.4103/0019-509X.197726. PMID: 28071630.

2. Taskinen S, Fagerholm R, Lohi J, Taskinen M. Paediatric ovarian neoplastic tumors: incidence, age at presentation, tumour markers and outcome. Acta Obstet Gynecol Scand. 2015 Apr;94(4):425-9. doi: 10.1111/aogs.12598. Epub 2015 Feb 27. PMID: 25640522.

3. Sud A, Jones ME, Broggio J, Loveday C, Torr B, Garrett A, et al. Collateral damage: the impact on outcomes from cancer surgery of the COVID-19 pandemic. Ann Oncol. 2020 Aug;31(8):1065-74. doi: 10.1016/j. annonc.2020.05.009. Epub 2020 May 19. PMID: 32442581; PMCID: PMC7237184.

4. Akula SM, Abrams SL, Steelman LS, Candido S, Libra M, Lerpiriyapong K, et al. Cancer therapy and treatments during COVID-19 era. Adv Biol Regul. 2020 Aug;77:100739. doi: 10.1016/j.jbior.2020.100739. Epub 2020 Jun 26. PMID: 32773105; PMCID: PMC7319627.

5. Nalini KB, Prathima PT, Shivakumar Shivanna, Mohan CVR. Anaesthetic implications and management of a giant ovarian cyst. doi:10.7860/ JCDR/2014/6680.4153.

6. CaiS,DaiR,MiJ,WangS,JiangY.Perioperative management of a patient with a giant ovarian tumor: a case report. Medicine. (Baltimore). 2020 Oct 9;99(41):e22625. doi: $\quad 10.1097 / M D .0000000000022625$. PMID: 33031322; PMCID: PMC7544284.

7. Bamba $\mathrm{K}$, Watanabe $\mathrm{T}$, Kohno $\mathrm{T}$. Anaesthetic management of a patient with a giant ovarian tumor containing 83 l of fluid. Springerplus. 2013 Sep 26;2:487. doi: 10.1186/2193-1801-2-487. PMID: $24102044 ;$ PMCID: PMC3790901.

8. Qureshi A. Diaphragm paralysis. Semin Respir Crit Care Med. 2009 Jun;30(3):31520. doi: 10.1055/s-0029-1222445. Epub 2009 May 18. PMID: 19452391.

9. O'Toole SM, Kramer J. Unilateral Diaphragmatic Paralysis. [Updated 2020 May 31]. In: StatPearls [Internet]. Treasure Island (FL): StatPearls Publishing; 2021 
Jan-. Available from: https://www.ncbi. nlm.nih.gov/books/NBK557388/

10. Dubé BP, Dres M. Diaphragm dysfunction: diagnostic approaches and management strategies. J Clin Med. 2016 Dec 5;5(12):113. doi: 10.3390/jcm5120113. PMID: 27929389; PMCID: PMC5184786

11. Szopa A, Domagalska-Szopa M. Correlation between respiratory function and spine and thorax deformity in children with mild scoliosis. Medicine (Baltimore). 2017 Jun;96(22):e7032. doi: 10.1097/ MD.0000000000007032.PMID: 28562557
; PMCID: PMC5459722.

12. Payo J, Perez-Grueso FS, FernandezBaillo N, Garcia A. Severe restrictive lung disease and vertebral surgery in a pediatric population. Eur Spine J. 2009;18 (12):1905-10. doi:10.1007/s00586-0091084-8

13. Oliveira J, Zagalo C, Cavaco-Silva P. Prevention of ventilator-associated pneumonia. Rev Port Pneumol. 2014 MayJun;20(3):152-61. English, Portuguese. doi: 10.1016/j.rppneu.2014.01.002. Epub 2014 Mar 24. PMID: 24674617. 